\title{
$\begin{array}{lllllllll}\mathrm{I} & \mathrm{N} & \mathrm{S} & \mathrm{T} & \mathrm{I} & \mathrm{T} & \mathrm{U} & \mathrm{T} & \mathrm{E}\end{array}$
}

\section{Deaths Exceed Births in Record Number of U.S. Counties}

KENNETH M. JOHNSON

$\mathrm{N}$ ew data released by the Census Bureau provide insights into the continuing influence of the Great Recession on U.S. demographic trends. The recession's impact on migration appears to be weakening, but it continues to have a negative impact on births. This has important implications for recent demographic trends in the United States.

Natural decrease occurs when more deaths than births occur in an area in a given year. The growing incidence of natural decrease in America has gone largely unnoticed, but new data released on March 14th demonstrate that natural decrease is no longer an isolated phenomenon. Last year, 36 percent of all U.S. counties experienced natural decrease. Deaths exceeded births in 1,135 counties, the most in U.S. history (see Figure 1). As recently as 2009, natural decrease occurred in just 880 counties. So the recent rise reflects sharply higher levels of natural decrease.

Counties are not the only entities impacted by these trends. Last year, for the first time in U.S. history, deaths exceeded births in two entire states. More people died $(12,857)$ than were born $(12,754)$ in Maine last year for the first time in history. West Virginia, the only other state to ever experience natural decrease, has had more deaths than births for a number of years.

\section{Births Diminished During Recession, Deaths Increased Due to Aging}

Natural decrease is more prevalent because births are diminishing. There were only 3,954,000 births last year, compared to a record 4,316,000 in 2006-2007. This represents a decline of 8.3 percent in just five years. The recession was closely associated

\section{Key Findings}

- A record 36 percent of all U.S. counties experienced natural decrease in 2012.

- For the first time in U.S. history, deaths exceeded births in two entire states: Maine and West Virginia.

- Births diminished during the recession, while deaths increased due to an aging population.

Figure 1. COUNTIES WITH MORE DEATHS THAN BIRTHS, 1950 TO 2012

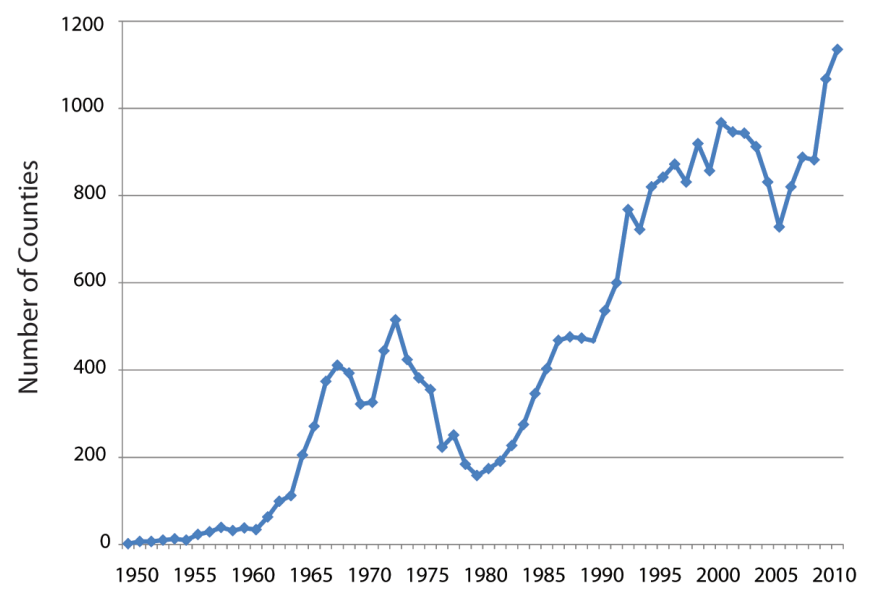

Source: U.S. Census FSCPE Estimates and National Center for Health Statistics Analysis: K.M. Johnson, Carsey Institute, University of New Hampshire

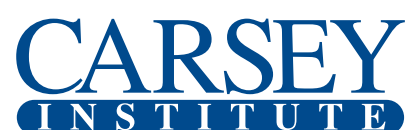

BUILDING KNOWLEDGE FOR FAmilies AND Communities
Huddleston Hall, 73 Main Street, Durham, NH 03824

(603) 862-2821 • www.carseyinstitute.unh.edu

This research was supported by the Annie E. Casey Foundation, the W. K. Kellogg Foundation, the New Hampshire Agricultural Experiment Station, the Carsey Institute, and anonymous donors.
UNIVERSITY

of NEW HAMPSHIRE 
with this fertility decline. Recent National Center for Health Statistics data ${ }^{1}$ show that both the number of births and fertility rates dropped sharply over the last several years. Young women are having fewer babies. Fertility rates have declined sharply for them, but they remained relatively stable for older women. The fertility rate for women 20-34 declined 12 percent in just three years. Hispanic fertility declined the most, especially among younger Hispanic women. Taken together, these data suggest that the impact of the recession has been particularly pronounced on younger women, who are likely delaying fertility. Whether they will make up for these foregone births later, or will simply have fewer children, remains to be seen. The growing number of deaths is also an important factor in the growth of natural decrease. Deaths last year $(2,513,000)$ exceeded those in any previous year. The growing number of U.S. deaths reflects the aging of the population.

Natural decrease is common in rural areas; last year 46 percent of all nonmetropolitan counties experienced natural decrease. In contrast, only 17 percent of urban counties experienced natural decrease last year. Natural decrease is also regionally concentrated. It occurred first in agricultural areas of the Great Plains, the Western and Southern Corn Belt, East and Central Texas, and in the Ozarks-as well as mining and timber-dependent counties of the Upper Great Lakes. It also occurred early in Florida counties that were among the first to receive retirement migrants.

\section{Causes and Consequences of Natural Decrease}

Natural decrease is caused by two interrelated demographic factors. ${ }^{2}$ The most influential of these factors is a local age structure that has few young adults of child-bearing age and a large surplus of older adults at high risk of mortality. Natural decrease is also more likely when fertility levels are low, as they are currently. Prolonged age-specific migration patterns produced the age structure shifts evident in natural decrease areas. For decades, migration drained young adults from these areas, while the older population remained (or grew through migration). The exodus of young adults and retention of older adults is not unique to natural decrease areas, but the magnitude of the trend is greater. In some areas of Florida, the Upper Great Lakes, and New England, an influx of retirement age population further increased the size of the older population at high risk of mortality.

The recent rise in natural decrease may be a harbinger of future trends. Once natural decrease begins in a county, it is likely to reoccur. Current demographic forces also increase the likelihood of future natural decrease. The large baby boom cohorts poised for retirement will increase the number of older adults at high risk of mortality dramatically over the next several decades. However, predicting the demographic future is always perilous. Natural decrease will likely continue in many areas and appear for the first time in others, but this is not a demographic certainty for all areas. The recent influx of immigrants to some regions of rural and urban America has brought a significant increase in births, but it has had little impact on mortality. This has reversed the incidence of natural decrease in some counties and diminished the likelihood of future natural decrease in others. ${ }^{3}$ Demography is not destiny, but one ignores it at their peril. With few young adults and a growing older population, the future viability of many natural decrease areas is not encouraging. Not all natural decrease areas face a bleak future. Economic development, an influx of minorities, high levels of civic engagement, and community cohesion have broken the downward spiral of natural decrease in some areas, but many remain at risk.

\section{E N D N O T E S}

1. For more information, see http://www.cdc.gov/nchs/data/hestat/births fertility_june_2012/births_june_2012.pdf.

2. K.M. Johnson, "The Continuing Incidence of Natural Decrease in American Counties," Rural Sociology, 76(1)(2011):74-100; K.M. Johnson, "Natural Decrease in the United States: More Coffins than Cradles," Policy Brief No. 30 (Durham, NH: Carsey Institute, University of New Hampshire, 2011), 1-6.

3. K.M. Johnson and D.T. Lichter, "Rural Retirement Destinations: Natural Decrease and the Shared Demographic Destinies of Elderly and Hispanics," in N. Glasgow and E. Berry (eds.), Rural Aging in 21st Century America (Dordrect, Netherlands: Springer, 2013), 275-294; D.T. Lichter, K.M. Johnson, R.T. Turner, and A. Churilla, "Immigrant Assimilation and Fertility in New Hispanic Destinations," International Migration Review 46(4) (2012): 767-791.

\section{A C K N O W L E D G M E N T S}

Research assistance was provided by Luke Rogers. Thanks to Jessica Carson, Curt Grimm, Laurel Lloyd, Beth Mattingly, and Amy Sterndale at the Carsey Institute for their helpful comments and suggestions.

\section{A B OUT THE AUTHOR}

Kenneth M. Johnson is senior demographer at the Carsey Institute and professor of sociology at the University of New Hampshire (ken.johnson@unh.edu). 